\title{
Fruit Based Carbonated Soft Drinks for Nutritional Security and Value Chain Development - A Review
}

\author{
Shilpi Verma* \\ Krishi Vigyan Kendra, Neemuch, M.P., India \\ *Corresponding author
}

\section{A B S T R A C T}

\section{Keywords \\ Carbonation, Fruit based, Beverages, Sensory evaluation, Physic- \\ chemical properties, Fruit juices \\ Article Info \\ Accepted: \\ 26 October 2018 \\ Available Online: \\ 10 November 2018}

Carbonation of fruit juices can also have a great scope in the future as carbonated soft drinks are very popular among youth and are known for their thrust quenching and refreshing properties but they lack the nutritional value. But the fruit juices which contain all the nourishing properties and the goodness of the fruit if they are carbonated then they can be a popular choice among youth for fruit drinks. Carbonated fruit based beverage is a new concept which provides nutritional elements of the fruit along with natural pigments and flavor in addition to carbonation effects.

\section{Introduction}

More than 2500 years ago, Hippocrates advised people 'Let food be thy medicine and medicine thy food.' During the last few decades scientific advances, social campaigns and interests in yoga and yogic way of life have made people aware of the role of diet in maintaining overall general health and combating chronic diseases. People throughout the world are tending to avoid foods rich in saturated fat, high calorie and salt. In this respect, the importance of liquid products in human diet is getting attention. Human history has been inextricably entwined with our search for and discovery of new foods and drinks. Indeed, human ingenuity in developing foods from their available raw material may be considered the essential reason why we have succeeded in populating all available land surfaces on the globe.

Time is ripe for total integration of food processing and waste utilisation to make the processing eco-friendly. Food processing is one of the priority sectors visualized by the Government of India. Strengthening of postharvest agro food system through viable food chain establishments can be one of potential factors for the economic progress of India. The "Rainbow Revolution" in the aftermath of the green and the white revolution stresses on the need to conserve the vast resource of 
fruits and vegetables with emphasis on the reduction of post-harvest losses. Value can be added to a commodity by upgrading its quality, reducing its perishability, extending shelf life, ensuring off-season availability, changing their form and purity as required in the market, transportation and marketing in remunerative markets.

Fruit juices occupy a unique position among those products classified as beverages. Being a source of energy, vitamins and minerals, juices are not only indispensable for the maintenance of health but also considered as the beverages of refreshment which quenches thirst and encourages liquid intake. The commercial viability of fruit juices in the preparation of carbonated drinks is practically limited. Inclusion of a fruit juice in soft drinks will not only impart its characteristic color, taste and aroma but also obviates use of synthetic additives and has some nutritional value. If fruit juices are added to these sweetened aerated waters, they not only impart nutrition but there is no need of synthetic additives. It may provide some more diversification to the soft drinks.

Carbonation of juices may also improve aroma, taste and nutritive value of the beverages. Finally, one could think of a new product development through carbonation in the form of a natural health drink, which would also serve as appetizer. Juicy fruits like amla and lime can be successfully transformed into drinks. Such fruit drinks are both refreshing and thirst quenching and are bound to cool stomach, tongue and set homes, offices tingling.

\section{Ingredients for carbonated beverage}

For preparation of carbonated beverages, the ingredients required are sugar, water, acidulants, flavourings, colouring, carbon dioxide, clouding agents and emulsifiers.

\section{Water}

Essential steps in the treatment of water are as chlorination, coagulation, clarification, lime softening, filtration through sediment filter or activated carbon filtration. Khurdiya (1989b) developed carbonated beverage and suggested that water for soft drinks must be clear and free from heavy metals, organic matters and must have low alkalinity.

The water can be treated with reverse osmosis, monochromatic UV radiation, ultrafiltration/microfiltration, chlorination, etc. and making it safe for soft drinks. (Ramchandran, 1988)

\section{Sugar}

Relative importance of color, fruity flavor and sweetness in overall liking of soft drinks was studied. The presence of flavourant significantly influence overall liking (Tuorila et al., 1984). The natural sweeteners which are nutritive include sucrose, liquid sucrose, liquid invert sugar, fructose, etc. Generally sucrose is used as sweetener. The synthetic sweeteners are saccharin, cyclamates, aspartame, etc. and have no nutrition (Khurdiya, 1989a).

\section{Acidulants}

It has been reported that various acids such as citric acid, tartaric acid, ascorbic acid, fumaric acid, phosphoric acid, malic acid, lactic acid and acetic acid are used in beverage to impart tartness/tang. It also acts as preservative by lowering $\mathrm{pH}$, citric acid are the most common acid used in the beverages.

It blends well with most of the fruit flavors. Phosphoric acid is mainly used in cola beverages. Ascorbic acid may be used to add vitamin $\mathrm{C}$ and it also acts as an antioxidants (Khurdiya, 1989a). 


\section{Carbon dioxide}

As reported by (Bright and Potter, 1970) the overall acceptability of carbonated versus non-carbonated apple juice. Their findings included overall preference for carbonated apple juice. The carbon dioxide is not only responsible for taste tingling effervescence but also provides anaerobic conditions for oxidation of ascorbic acid (Khurdiya, 1989a).

Carbon dioxide gas not only imparts a distinctive taste, zest and sparkle to beverage but also inhibits or destroys the harmful bacteria (Juneja and Checker, 1999)

\section{Preservatives}

The principal preservative used in carbonated beverages is sodium benzoate. Carbon dioxide and acid have also preservative action against the growth of micro-organisms.

\section{Fruit Based Carbonated Drinks}

The carbonated apple juice produced at various levels of soluble solids (Brix) and carbonation using response surface methodology with treatment levels based on a rotatable design. Sensory attributes of aroma, sweeteners and response model derived where appropriate. Aroma intensity was not significantly affected by level of soluble solid or carbonation level. Sourness and body (mouthfeel) were modeled with significant linear effects. The model derived for the acceptability of the juice had a ridge of high acceptability running through the range of typical soluble solids and carbonation levels (Mclellan, et al., 1984).

The Food Produce Order Specifications for carbonated beverage were juice not less than 10 per cent, TSS not less than $10^{\circ}$ Brix and carbon dioxide 1 to $8 \mathrm{~g}$ per litre. (Lal et al., 1986)
The titratable acidity (TA) of clarified pineapple juice adjusted to $0.65,0.75,0.85$ and $0.95 \%$ through ion exchange treatment followed by the addition of the citric acid. Each lot of the juice was carbonated to three levels of $\mathrm{CO}_{2}$ content $(2.5,3.0$ and 3.5 garliquid volumes). Preference panels were conducted on these juices, holding either TA or gas-volume constant and varying the other parameters. Although few statistical significant differences were found on overall preference for a $0.75 \% \mathrm{TA}$, low carbonation product was observed. (Baranowski and Park, 1987)

The effect of methods of lime juice extraction on the acceptability of lime juice based carbonated drinks was investigated. Different treatment of extraction namely, manually with a wooden lime squeezer, hand pressing, hand operated wooden basket press and grater were studied.

The juice was stored at $3^{0} \mathrm{C}$ until required. Hand pressing gave a higher yield of juice. The grating and basket pressing method resulted in highest $\mathrm{pH}$ (2.75) and lowest acidity $(3.39 \%)$ in the juice. The best drink for carbonation could be made with brix/acid ratio of 50. All drinks were acceptable except those prepared by grating. The combined juice of the cut fruit and grated whole limes in the ratio of 2:1 gave an acceptable carbonated lime drink with stable cloud (Khurdiya, 1988).

The drink containing 3 per cent lime juice with 0.2 per cent acidity, $10^{\circ}$ Brix TSS and carbonated under 100 psi of $\mathrm{CO} 2$ adjudged was reported the best Khurdiya, 1989b). The ingredients for preparation of carbonated beverages were water, sweeteners, acidulants, colorings, flavoring, carbon dioxide, clouding agents and emulsifiers (Khurdiya, 1989a). A study to find out the feasibility of fruit based carbonated drinks from lime, phalsa, jamun, 
ber and apple was described for processing, preservation and formulation of their carbonated drinks (Khurdiya, 1990).

Edible bulbs of ripe jackfruit (Artocarpus heterophyllus Lam.) are consumed for their fine taste and pleasant aroma. The edible portion is about $30 \%$ by weight. About $50 \%$ of fruit composed of rind and unfertilized floral parts, which are also rich in jackfruit flavor, are usually discarded as waste, because they are fibrous. A process for the preparation of clarified juice has been developed and involves treatment of the jackfruit waste with pectic enzyme at $0.3 \%$ concentration (v/w), incubation for $2 \mathrm{hr} 40^{\circ} \mathrm{C}$ and subsequent filtration, giving about $60 \%$ yield of clarified juice having $23^{\circ}$ Brix and $0.15-0.20 \%$ acidity. Sensory evaluation of ready-to-serve (RTS) beverages (12\% juice, $15^{\circ}$ Brix sugars and $0.3 \%$ acidity) without and with carbonation at 3 levels $(\mathrm{CO} 2$ gas pressures $0.775,2.092$ and $3.685 \mathrm{~kg} / \mathrm{cm} 2$ ) by a 15-member trained panel revealed that the product was highly acceptable either without or with carbonation at $0.775 \mathrm{~kg} / \mathrm{cm} 2$, compared to higher levels of carbonation. It is concluded that preparation of beverage from jackfruit waste as a byproduct, besides processing of bulbs and seeds, brings about the effective utilization of jackfruit to over 80\% (John and Narasimham, 1993).

Processing and storage of carbonated guava beverage was studied. Guava cv. Allahabad Safeda was crushed and treated with pectic enzymes at 0.1 per cent concentration (w/v), incubated for 1 hour at $40-50^{\circ} \mathrm{C}$ and the liquefied juice having $10.8^{\circ}$ Brix T.S.S. and 0.65 per cent acidity was used for carbonation. The juice was converted into sugar syrup having 40 per cent guava juice at $40^{\circ}$ Brix T.S.S. and 1 per cent acidity. After dosing $50 \mathrm{ml}$ of it into a glass bottle of $200 \mathrm{ml}$ capacity filled with chilled $\left(4-6^{\circ} \mathrm{C}\right)$ carbonated water at 80 psi pressure of $\mathrm{CO} 2$ gas, the bottle was sealed with crown cork and heat processed at $60^{\circ} \mathrm{C}$ for $30 \mathrm{~min}$. The guava carbonated beverage could be stored for 3 months at room $\left(23-41^{\circ} \mathrm{C}\right)$ and low (3$5^{\circ} \mathrm{C}$ ) temperatures and was found acceptable with respect to colour, flavour and overall quality. Heat processing improved the flavour of carbonated guava beverage and contained no detectable microbes. As stated about development of technologies at IARI, New Delhi for better utilization of fruits and vegetable varieties useful to food processing industries. They emphasized on the uses of fruit based carbonated drink of Jamun, phalsa, grapes etc. because of better utilization of fruit juices/pulp, better nutrition, beneficial to grower and consumer and reduction of losses as well as more value added products. The drinks contained pure fruit juice and no additives. Roy et al., 1996)

An attempt to produce carbonated beverages from grapes, lime and phalsa juice and their pomace extract was made. Pomace extract possessed the chemical constituents lowest than juices which were improved when mixed with original juice. When juice and pomace extract were mixed together the production of bottled beverage increased by 1.8 (phalsa), 2.8 (lime) and 1.41 (Grape) folds respectively. Beverage made from juice, pomace extract and their combination did not differ significantly in respect of color, flavor and overall acceptability and also increased the beverage yield (Khurdiya et al., 1997).

A formulation was standardized for orange concentrate based carbonated beverage. The carbonated beverage made from syrup base containing 7.5 per cent orange concentrate was equivalent to about 10 per cent of single strength orange juice which was considered optimum. The carbonated beverage was made by post mix method and a beverage with Brix to acid ratio of 45 and carbonated at $80 \mathrm{psi}$ was found to be the best (Khurdiya, 1998). 
Previous studies demonstrated that a noncarbonated blackcurrant juice drink with added calcium produced little erosion of enamel in vitro and in situ by comparison with other low $\mathrm{pH}$ fruit drinks. West et al., (2003) aimed to evaluate the erosive effects in situ of an experimental formulation carbonated drink with added calcium, compared to a conventional carbonated drink over a 20 day period using a similar design as in previous studies. The study was a single centre, single blind; randomized placebo controlled three cell crossover design involving 15 volunteers. The test drinks were an experimental carbonated ready-to-drink (RTD) blackcurrant drink, a conventional carbonated RTD orange drink and water. Two enamel samples were retained in situ, in the midline of the hard palate on an upper removable acrylic appliance. Drinks were 250 $\mathrm{ml}$ volumes consumed four times per day during 20 working days. Measurements of enamel loss were made on enamel samples after days 2, 5, 10, 15 and 20 by profilometry. The experimental carbonated blackcurrant drink caused significantly less enamel loss than the conventional carbonated orange drink at all-time points measured, but was not significantly different from water at days 2, 5 and 20. This study has shown that it is possible to modify carbonated soft drinks in a manner similarly shown with non-carbonated soft drinks, to minimize dental erosion.

The purpose of the study conducted by Ibrahim (2007) was to determine the nutritional and industrial value of carbonated roselle beverage produced from roselle calyces. Calyces of Alrahad cultivar were in the present investigation. Proximate chemical analysis for roselle calyces was carried out to determine the levels of the various nutrients in the calyces. The results showed that the roselle calyces contained $7.6 \%$ moisture, $10 \%$ crude protein, $10 \%$ crude fiber, $0.6 \%$ fat, $9.2 \%$ ash and $62.6 \%$ carbohydrate. Roselle calyces were found to contain $0.548 \%$ Calcium, $0.201 \%$ Magnesium and $0.016 \%$ Iron. The results of present work indicated that the roselle calyces is nutritional acceptable since it can provide both nutrients and minerals. Carbonated roselle beverage was prepared from concentrated calyces extract, sugar (sweetener), gum Arabic (stabilizer) and sodium benzoate as preservative. The effect of storage at room temperature $\left(30-35^{\circ} \mathrm{C}\right)$ for 4 months on $\mathrm{pH}$, acidity, total soluble solids and color intensity of the roselle carbonated beverage was investigated. The results indicated that storage slightly increased the $\mathrm{pH}$ value and decreased the acidity, total soluble solids and color intensity. The microbial analysis for this beverage was carried out to determine the effective role of the preservative $(0.05 \mathrm{~g} /$ litre sodium benzoate) against microorganism. The results of the study showed that the beverage was devoid from yeast and mould and has low bacterial count. This beverage can compete with other carbonated beverages. The panel test confirmed the good quality, palatability and overall acceptability of roselle carbonated drink compared to similar types of drinks.

Ilamaran and Amutha (2007) studied the effect of total soluble solids and $\mathrm{CO}_{2}$ presssure on Physico-chemical and sensory qualities of carbonated banana and sapota beverages. Banana (Musa paradisiaca) and sapota (Achras sapota) fruits were pulped and treated with pectinase at $0.5 \%$ concentration (w/v), incubated for 2-3 h at ambient temperature (AT) $\left(32-37^{\circ} \mathrm{C}\right)$. The clarified juice samples were used to prepare carbonated beverages by adjusting the total soluble solids $\left(9,12\right.$ and $\left.15^{\circ} \mathrm{B}\right)$ keeping the acidity constant at $0.25 \%$ and varying the carbonating pressure as 0 (non-carbonated), 80,100 and 120 psi. The carbonated banana and sapota beverage could be stored for 6 months at AT and low temperatures $\left(3-5^{\circ} \mathrm{C}\right)$ and was acceptable with respect to colour, 
flavour, taste and overall acceptability. Heat processing and carbonation improved the colour, flavour and taste of the carbonated banana and sapota beverages.

Investigation undertaken by Sandhan and Kushare (2008) to prepare carbonated beverage from pomegranate juice of Ganesh variety showed that the yield of pomegranate juice obtained on whole fruit basis was 43 per cent while it was 68 per cent on aril weight basis. The carbonated beverage was prepared with $10,15,20$ percent pomegranate juice with blending of ginger juice at 1,2, 3 per cent by maintaining the TSS at 15 Brix and acidity 0.30 per cent. Based on the organoleptic evaluation, carbonated beverage with 10 per cent pomegranate juice and ginger juice 1 per cent was best among all the levels.

Sandhan et al., (2009) investigated the storage life of carbonated beverage from pomegranate juice in different storage condition. Carbonated beverage with 10 per cent pomegranate juice and ginger juice 1 per cent was stored in ambient storage condition and cool storage. Increase in T.S.S., pH, reducing sugars, non-reducing sugars and total sugars as well as decrease in titrable acidity, ascorbic acid, anthocyanin content and score for all sensory attributes, was recorded in all treatments irrespective of storage condition. The rate of increase in T.S.S., pH, reducing sugars, non-reducing sugars and total sugars as well as decrease in titrable acidity, ascorbic acid, anthocyanin content and score for all sensory attributes was higher in ambient condition than cool storage condition.

Sapota fruits were pulped and treated with pectinase enzyme at $0.5 \%$ concentration $(\mathrm{w} / \mathrm{v})$ incubated for $2-3 \mathrm{~h}$ at AT $\left(32-37^{\circ} \mathrm{C}\right)$. The clarified juices were used to prepare carbonated beverages by adjusting the total soluble solids $\left(9,12\right.$ and $15^{\circ}$ B) keeping the acidity constant at $0.25 \%$ and varying the carbonating pressure as 0 (non-carbonated), 80,100 and 120 psi. The carbonated sapota beverage could be stored for 6 months at ambient (AT - 32-37 $\mathrm{C}$ ) and low temperatures (LT - 3-5 DC) and was found acceptable with respect to colour, flavour, taste and overall acceptability. Heat processing and carbonation improved the colour, flavour and taste of the carbonated sapota beverage (Ilamaran and Amutha, 2009).

According to previous research, tender coconut water (Cocos nucifera) is one of the highest sources of electrolytes known to man. It contains sugar, vitamins, minerals, potassium, magnesium, fibre, proteins and antioxidants. Coconut flesh is sweet and contains less sugar, more protein than many popular fruit. It has less fat, and these have a high proportion of saturated fat, and it is relatively high in minerals such as iron, phosphorus and zinc. Both tender coconut water and coconut flesh are used as food and medicine. Recently, modern medicinal research has confirmed many health benefits traditionally attributed to this remarkable tender coconut water and flesh. In this research the coconut was studied as a source of nutrients, as well as how to retain these nutrients during processing for the preparation of a carbonated beverage \& coconut jam. Carbonated tender coconut water and coconut jam provide a range of nutrients which are necessary for human health. A series of chemical, nutrient and sensory tests for beverage and jam were conducted. The developed carbonated tender coconut water had many beneficial effects because it had added lime juice and vitamin $\mathrm{C}$ (ascorbic acid). According to analysis of the results, the two products were nutritionally rich (Silva and Bamunuarachchi, 2009).

Arora and Agarwal (2009) studied the effect of method of preservation of pulp on the quality of carbonated and noncarbonated 
beverages prepared from peach fruit. Peach pulp preserved by different methods, i.e., processing at $100 \mathrm{C}$ for $30 \mathrm{~min}$, potassium metabisulphite (KMS; 2,000 ppm), sodium benzoate $(750 \mathrm{ppm})$ and mixture of KMS and sodium benzoate (1,000 and $375 \mathrm{ppm})$ had no significant effect on total soluble solids (TSS), acidity, TSS : acid ratio, $\mathrm{pH}$ of carbonated as well as noncarbonated beverages. Carbonated beverages prepared from pulp with $750 \mathrm{ppm}$ of sodium benzoate retained significantly $(\mathrm{P} \leq 0.05)$ higher carbon dioxide $(\mathrm{CO} 2)$ content and $\mathrm{CO} 2$ gas: volume during storage. Color of the beverages prepared from peach pulp containing KMS was better but the beverages prepared from peach pulp preserved by processing and addition of sodium benzoate were organoleptically more acceptable. Both carbonated and noncarbonated drinks remained organoleptically acceptable throughout storage. Suspension of carbonated beverages was significantly $(\mathrm{P} \leq 0.05)$ higher during storage as compared with noncarbonated beverages.

Vadakkan et al., (2010) prepared sweet orange ready-to-serve (RTS) carbonated beverage prepared by extracting and clarifying the juice and adjusting the total soluble solids (TSS) to 56, 60, 64 and 68 ${ }^{\circ}$ Brix with sugar and acidity to $0.5,1.0$ and $1.5 \%$ with citric acid. It was observed that the beverage with $60{ }^{\circ}$ Brix TSS and $1.0 \%$ acidity was found superior in sensory characteristics with respect to colour, aroma, taste, mouthfeel and overall acceptability followed by beverage with $60{ }^{\circ}$ Brix TSS and $0.5 \%$ acidity over the beverage prepared by using other levels. The beverage carbonated at 120 psi pressure scored highest for sensory quality than those at 75 and 120 psi.

The demand for high quality food products is growing rapidly these days. A natural taste and a fresh like quality are highly appreciated.
Custard apple carbonated beverage was prepared by Patil, et al., (2011). The physicochemical characteristics and organoleptic quality of carbonated beverages was evaluated. The chemical composition of custard apple pulp was carried out and it was found that pulp was source of carbohydrate $23.9 \%$ and good source of protein $1.6 \%$. The nutritive value of custard apple carbonated beverage showed it was good source of carbohydrate $(12.9 \%)$, protein $90.7 \%$ ) and fat $(0.18 \%)$.

'Thompson seedless' grapes (Vitis vinifera) possessing $<13^{\circ}$ brix and $>1.0 \%$ acidity were used in the preparation of beverages with and without carbonation. Sour grape juice was extracted, bottled and clarified by racking for three months. Palatable blended grape beverages were also prepared using sour grape juice with phalsa / purple grape juice. Process parameters such as quantity of juice, blending proportions and brix / acid ratio for different beverages were optimized. Squashes were prepared by maintaining brix at $45^{\circ}$ and acidity $0.75 \%$. Ready-to-serve (RTS) beverages were standardized with brix $15^{\circ}$ and acidity $0.14 \%$.

The appearance, color and flavor characteristics of sour grape beverages were improved by blending with purple grape juice and phalsa juice at 2:1 and 1:1 ratios respectively. A set of carbonated beverages in the above combinations were also prepared to check their compatibility and acceptability. A marginal rise in total sugars and decrease in acidity were observed in all beverages after 6 months of storage. Sensory evaluation indicated that carbonated beverages were highly acceptable than plain beverages throughout the storage period. Highest scores of 7.4 and 7.5 were recorded for blended grape beverages with purple grape and phalsa juice respectively even after a storage period of 6 months (Balaswamy et al., 2011). 
Jori, et al., (2013) prepared carbonated pineapple fruit juice. Different parameters such as shelf life of pineapple juice, its sensory evaluation with respect to the concentration $(10 \%, 12 \%$, and $15 \%$ of juice with carbonation at $100 \mathrm{psi}$ ) and time were studied. The chemical factors such as acidity, $\mathrm{pH}$, and sugars were studied and the changes were observed with respect to time. The sensory evaluation study was done with Hedonic scale along with the help different panel members. The best results were obtained for $15 \%$ fruit juice concentration with the initial values of $\mathrm{pH}$, acidity and Total sugars $4.10,0.58 \%, 13.8^{0} \mathrm{Bx}$, was reduced to 2.98, 0.63 and $12^{0} \mathrm{Bx}$, after 9 weeks respectively. The decrease in the $\mathrm{pH}$ value and increase in the acidity with respect to time period was observed which indicates the increase in the shelf life of prepared carbonated pineapple juice.

Luciana et al., (2013) determined the shelf life of a carbonated cashew beverage with fructooligosaccharides added using two different processing methods: by using additives (potassium sorbate / sodium benzoate) without pasteurization and by using pasteurization at $90^{\circ} \mathrm{C}$ for 1 minute with addition of preservatives, physic-chemical analysis $(\mathrm{pH}$, titratable acidity, soluble solids $\left({ }^{0}\right.$ Brix, vitamin $\mathrm{C}$, reducing sugars) and sensory evaluation (triangular test and acceptance test) were performed throughout 60 days of storage at $20^{\circ} \mathrm{C}$. the results show a decrease in vitamin $\mathrm{C}$ content in both processing methods $(\mathrm{p}<0.05)$, while the other physic-chemical parameters were similar and stable during the shelf life period. Hedonic scores between 5.0 9 neither liked, nor disliked) and 6.0 (slightly liked) were obtained during the test period. The results suggest that it is possible to develop a potentially prebiotic cashew beverage that presents suitable physic-chemical and sensory parameters.
Enormous fruit production and its potential are marred by colossal wastage, very low level of processing and non-availability of post-harvest infrastructure. Delay in the use of harvested food products takes away their freshness, palatability, appeal and nutritive value. The commercial viability of fruit juices in the preparation of carbonated drinks is practically limited. Juicy fruits like aonla and lime can be successfully transformed into drinks. Hence an attempt by Verma et al., (2014) was made to develop and assess the quality of fruit based carbonated soft drinks. For developing fruit based carbonated soft drinks fruit syrup of aonla and lime with TSS 50 per cent was standardized and used in preparation of carbonated soft drinks blends in the ratio of 60:0, 30:30 and 0:60 ml. The developed blends were analyzed for nutrient composition, sensory quality, physicochemical and microbial load. The pH, TSS (0 Brix) and titratable acidity of blends ranged between 3.0 to $2.5,15.70$ to 20.25 and 0.256 to 0.671 respectively. The blends had a good amount of vitamin $\mathrm{C}$ and total sugar content. All the blends were found highly acceptable. Pure aonla drink was accepted most with highest vitamin C content (267.93 $\mathrm{mg} \%$ ). The study therefore recommends that there is a need to popularize nutritionally superior aonla based carbonated beverages as better substitute for commercial carbonated beverages.

Wagh, et al., (2014) developed a carbonated ready to serve (RTS) beverage from pomegranate juice. The matured and freshly harvested fruits of $\mathrm{Cv}$. Ganesh and Bhagwa were washed and the arils were separated by using operated arils extractor developed by CIPHET, Ludhiana. The juice was extracted by using screw type juice press followed by filtration. The beverage was prepared by adjusting the sugar syrup $60^{\circ}$ Brix and $0.5 \%$ acidity by adding citric acid and then carbonated at 80,100 and 120 psi pressure 
respectively. The resultant RTS beverage was then analyzed for various physico-chemical and organoleptic characteristics. The study revealed that the RTS beverage prepared by using 600 Brix juice of $0.5 \%$ acidity and 80 psi $\mathrm{CO} 2$ pressure in low temperature of bhagwa cultivar was found better in organoleptic characteristics as compared to the rest of treatment.

\section{Organoletpic evaluation of carbonated beverage}

Guava based carbonated drink prepared with $40 \mathrm{ml}$ of syrup with 8 per cent juice, $11.7^{\circ}$ Brix TSS, 0.26 per cent acidity had scored maximum organoleptic score (Khurdiya, et al., 1996). Khurdiya (1998) studied the factors affecting the quality of orange concentrate based carbonated beverage. A drink containing 7.5 percent orange concentrate, $10.4^{\circ}$ Brix T.S.S., 0.28 percent acidity, $3.20 \mathrm{pH}$ was adjudged. He further reported that lime based carbonated drink having (Brix-Acid ratio) BAR-50 at 100 psi of $\mathrm{C} 02$ gas was adjudged as the best, phalsa drink with 37.5 per cent juice having $25 \mathrm{BAR}$ and 80 psi of $\mathrm{CO}_{2}$ gas, jamun drink with 30.9 per cent juice having 28.57 BAR and 80 psi of $\mathrm{C} 02$ gas, ber drink with 33.3 per cent juice $45 \mathrm{BAR}$ and 120 psi of $\mathrm{CO}_{2}$ gas and $41.4 \mathrm{BAR}$ with $36 \mathrm{ml}$ concentrate at 100 psi $\mathrm{C} 02$ from apple were found to be the best. The carbonated beverage prepared from grapes with 0.3 per cent acidity and $14^{\circ}$ Brix T.S.S. scored for the maximum organoleptic properties (Rokade, et al., 2001).

\section{Chemical composition of carbonated beverage}

A beverage prepared by using 25 per cent guava fruit juice contained 0.5 per cent acidity and 20 per cent TSS. The carbonated beverage prepared from Thompson Seedless variety of grape contained T.S.S. (11.9- $14^{\circ}$ Brix), acidity (0.25-0.30 per cent), total sugar (11.2-12.9 per cent), reducing sugar (4.88-5.40 per cent), $\mathrm{pH}(2.95-3.65)$ and Brix Acid ratio (40.7:55.0). (Rokade, et al., 2001).The chemical composition of RTS prepared from aonla-mango blend had TSS 14 to $15^{\circ}$ Brix, acidity $0.23-0.25$ per cent, ascorbic acid 25.82 to $49.20 \mathrm{mg} / 100 \mathrm{~g}$ and reducing sugars 0.3 to 0.9 per cent (Bhosale, et al., 2000).

\section{Storage of carbonated beverage}

Jain and Borkar (1970) prepared the guava based carbonated beverage. They reported that carbonated guava beverage can be kept without spoilage for over a period of 15 days, after that beverage showed the signs of fermentation. They also suggested that readyto-serve beverages are usually not meant for prolonged storage and are consumed within a fortnight.

Lal et al., (1986) reported that carbonated beverage could be stored for a week at ambient conditions without addition of any preservative. It is however, necessary to add 0.005 per cent of sodium benzoate to the finished product, if the beverage is to be kept for a longer period (Khurdiya et al., 1996). Reported that the carbonated guava beverage could be stored for 3 months at room temperature $\left(23-41^{\circ} \mathrm{C}\right)$ and low $\left(3-5^{\circ} \mathrm{C}\right)$ temperature and was found acceptable with respect to color, flavor and overall quality.

Jadhav et al., (2002) observed that the carbonated beverage developed from tamarind juice stored at cold temperature showed the maximum storability of 35 days without affecting taste and flavor. Ghume (2003) reported an increasing trend in T.S.S., reducing sugars, non-reducing sugars and total sugars during storage of carbonated beverage prepared from riped guava fruits, the same time decrease in ascorbic acid was 
recorded in ambient and cool storage conditions. Sandhan (2003) reported an increasing trend in T.S.S, $\mathrm{pH}$, reducing sugars, non-reducing sugars and total sugars during storage of carbonated beverage prepared from pomegranate fruit juice. The same time decrease in acidity and ascorbic acid was recorded in ambient and cool storage conditions.

It can be concluded that fruit juices could be successfully incorporated with carbonation. These fruit based carbonated drink will turn out to be beneficial for mass consumption due to their nutrients and also prove to be an alternate to popular soft drinks. The fruit juice carbonated drink seems to hold good promise in the manufacture of value added nutritious beverages. Such beverages are highly acceptable as refreshing flavoured drinks. The new product so formulated is expected to provide a profitable outlet for health conscious population. The procedures employed for preparation of the drinks are simple, convenient and economical.

\section{References}

Arora, S., \& Aggarwal, P. (2009). Effect of method of preservation of pulp on the quality of carbonated and noncarbonated beverages prepared from peach fruit. Journal of Food Quality, 32(6), 695-708.

Balaswamy K, Rao PP, Nagender A, Satyanarayana A (2011) Preparation of Sour Grape (Vitis Vinifera) Beverages and Evaluation of their Storage Stability. J Food Process Technol 2:116. doi:10.4172/2157-7110.1000116

Baranowski, J.D and Park, S.S.(1987), Effects of titratable acidity and carbonation level on the preference of clarified pineapple juice, Journal of Food science, 49 (4): 1220-1221.
Bhosale, V. J., Kute, L. S. and Kadam, S. S. 2000. Studies on preparation of RTS beverage from aonla. Beverage Food World, 27(2):24-27

Bright, R. A. and Potter, N. N. 1970. Acceptability and properties of carbonated apple juice. Food Prod. Development, 13(4):34.

Ghume, S. B. 2003. Preparation of carbonated beverage from guava fruit. M.Sc. (Agri.) Thesis, Mahatma Phule Krishi Vidyapeeth, Rahuri-413 722, Dist. Ahmednagar, M. S., India.

Gonzales ON, Alejo JV, Brillante J, Valdecanas M (1985) Process for preparing non-carbonated and carbonated coconut water. Cocomunity APCC/QS/03: 31- 42.

Ibrahim, S. O. A. A. (2007). An Attempt to Prepare A Carbonated Beverage from Roselle (Hibiscus Sabdariffa L.) Concentrate (Doctoral dissertation, University of Khartoum). http:// khartoumspace.uofk.edu/handle/123456 789/12796

Ilamaran M and Amutha S (2007), Effect of total soluble solids and $\mathrm{CO} 2$ presssure on Physico-chemical and sensory qualities of carbonated banana and sapota beverages. J. Food Sci. Technol., 44(2): 178-182.

Ilamaran M and Amutha S (2009), Studies on the biochemical and sensory qualities of enzymatic clarified carbonated sapota beverages, Asian Journal of Home Science, Vol. 3 (2): 230-233

Jacob John P. and P. Narasimham (1993), Processing and Evaluation of Carbonated Beverage from Jackfruit Waste (Artocarpus heterophyllus), Journal of Food Processing and Preservation, Volume 16, Issue 6, January 1993, Pages 373-380

Jadhav, H.M., Kotecha, P.M. and Kadam, S.S. (2002). Studies on preparation and storage of carbonated beverage from 
tamarind juice. Beverage and Food World, 28 (9): 28-29.

Jain, N. L. and Borkar, D. H. 1970. Preservation and storage ability of ready to-serve beverage from guava (Psidium guajava). Indian Food Packer, 24(2):2933.

Jori, D., M. Ladole, A. Gore and V. Bhand, (2013) Study on effect of carbonation on storage and stability of pineapple fruit juice, International Journal of Engineering Research and Technology, vol. 2 (12), pp. 1841-1847.

Juneja, K. K. and Checker, S. 1999. Quality control of beverages: Non-alcoholic and alcoholic. Processed Food Industry, 2(10): 15-13.

Khurdiya D S (1998). Orange concentrate based carbonated beverage. J Fd Sci Technology, 27: 394-396

Khurdiya DS (1988) Preparation of lime juice for carbonated drink. Journal of Food Science and Technology 25: 315-316.

Khurdiya DS, Islam and Sen, S. (1997) Production of carbonated Beverage from Phalsa, Lime and Grape Juice and pomace extractdrinks. Indian Food Packer, 51: 55- 61.

Khurdiya, D.S. (1989a), Carbonation in fruit beverages, Beverage and Food World, 16 (2): 09-11.

Khurdiya, D.S. (1989b). Factors affecting the quality of lime juice based carbonated drink. Indian Food Packer, 43 (4): 1720.

Khurdiya, D.S. (1990). A study of fruit juice based carbonated drinks. Indian Food Packer, 44(6): 45-50.

Khurdiya, D.S., Islam and Verma, O.P. (1996). Processing and storage of carbonated guava beverage. J. Food Proc. And Preservation, 20 (1): 79-86

Lal, G., Siddappa, G. S. and Tondon, G. L. 1986. Preserves, candies and crystallized fruits. In: 'Preservation of
Fruits and Vegetables'. ICAR, New Delhi, pp. 198-213.

Luciana C. Nogueira, Rafael T Parmanhane, Adriano G. Cruz, MariaIvone M.J. Barbosa (2013), Physico-chemical stability and sensory acceptance of a carbonated cashew beverage with fructooligosaccharides added, African Journal of Biotechnology, vol.12 (20), pp-2986-2989.

Mclellan, M.R.; Barnard, J and Qurale, DT (1984), sensory Analysis of Carbonated apple juice using response surface methodology. Journal of Food science, 49 (6):1595-1597

Patil, S.R., Kurhekar, S.P. and Patil, R.R (2011), Study on development of custard apple carbonated beverage, International Journal of Processing and post-harvest technology, 2(1):56-58

Ramchandran, M. 1988. The role of water treatment in the manufacture of beverage and processed food. Beverage Food World, 15(1):81-82.

Rokade, A.S., Kotecha, P.M. and Kadam, S.S. (2001). Studies on preparation of carbonated beverages from grapes. Beverage and Food World, 28 (9): 2829.

Roy, Susanta K.; Khurdiya, D.S. and Pal, R.K. (1996), Fruits and vegetable Varities and technologies developed at IARI useful to food processing industries, Ind. Fd. Pack. 50 (1): 49-63

Sandhan VS and Kushare, B.M (2008) Preparation of carbonated beverage from pomegranate (Punica granatum L.) The Asian J. Hort., June 2008 Vol. 3 (1): 66-69

Sandhan VS, Nandre DR and Kushare, B.M (2009), Storage studies of carbonated beverage from pomegranate juice, International Journal of Agricultural Sciences, Vol. 5 (1), 2009: 217-220

Sandhan, V. S. (2003). Preparation of carbonated beverage from pomegranate 
(Punica granatum L.) fruits cv. Ganesh and Mridula. M. Sc. (Agri.) Thesis, Mahatma Phule Krishi Vidyapeeth, Rahuri-413 722, Dist. Ahmednagar, M. S., India.

Silva, P. S. A., and Bamunuarachchi, A. (2009). Manufacture of carbonated tender coconut water and development of a process for the utilization of coconut flesh. Asian Journal of Food and Agro-Industry, 2(02), 210-213.

Tuorila-OHikainen, H., Maholmaki-Kultanen, S. and Kurkela, R. 1984.Relative importance of colour, fruity flavour and sweetness in the overall liking of soft drinks. J. Food Sci. 49:1598-1600.

Vadakkan, S.R., Sakhale, B.K., Pawar, V.D., Miniyar, U.G. and Patil, B.M. (2010). Studies on effects of total soluble solids, acidity and carbonation levels on quality of sweet orange beverage, Food Sci. Res. J., 1 (2): 134-136.
Verma S, Gupta S and Sharma B (2014) Utilisation of aonla and lime for development of fruit based carbonated soft drinks, International Journal of Farm Sciences 4(2): 155-162

Wagh, D.J.; Kadam A.R and Kapse B.M. (2014) Studies on development of carbonated pomegranate RTS beverage, Ecology, Environment and Conservation Paper, Vol 20, Issue 4, Page No. (1949-1953)

West, N.X., J.A Hughes, D.M Parker, M Moohan and M Addy (2003) Development of low erosive carbonated fruit drinks 2. Evaluation of an experimental carbonated blackcurrant drink compared to a conventional carbonated drink, Journal of Dentistry July 2003, Vol. 31(5): 361-365, doi:10.1016S0300-5712(03)00046-0

\section{How to cite this article:}

Shilpi Verma. 2018. Fruit Based Carbonated Soft Drinks for Nutritional Security and Value Chain Development - A Review. Int.J.Curr.Microbiol.App.Sci. 7(11): 3084-3095. doi: https://doi.org/10.20546/ijcmas.2018.711.354 